\title{
Etnograficzne atlasy Polski. Prolegomena
}

The ethnographic atlases of Poland. Prolegomena

MIRANDA: Wszystko to odległe

I podobniejsze do snu niż wspomnienia

Realnych zjawisk. (...)

PROSPERO: Co jeszcze

Widzisz na mrocznym tle, w otchłani czasu?

Pamiętasz czasy przed przybyciem tutaj?

Szekspir, Burza (przekład S. Barańczaka)

Pamięci profesor Bronisławy Kopczyńskiej-Jaworskiej znakomitej badaczki tradycyjnej kultury Autor

\section{Wprowadzenie do metody etnogeograficznej - technika kartograficzna}

Wiedza o przeszłości kultury opiera się na badaniach zachowanych fragmentów działalności ludzkiej. Jedne z nich mają charakter materialny, inne przetrwały w języku, życiu codziennym, obrzędach, folklorze i innych przejawach. Odtwarzaniem tej historii zajmują się badacze różnych dyscyplin, wśród nich etnologowie. Jednym z celów, jakie stawia sobie etnologia, jest odtworzenie genezy elementów i całych 
kompleksów kultury tradycyjnej. Posiłkuje się przy tym paroma sposobami, w tym metodą etnogeograficzną.

Metoda etnogeograficzna została już kilkakrotnie opisana². Tu przypomnę tylko, iż do etnologii polskiej wprowadził ją K. Moszyński. Posłużył się nią pisząc monumentalne dzieło Kultura ludowa Słowian (1929, 1934, 1939), a w polemicznym artykule Niektóre przyczyny zróżnicowania kultury ludowej w Polsce wyjaśniał genezę tradycyjnej kultury w naszym kraju, wskazując na przyczyny natury geograficznej (Moszyński 1937/1938).

Częścią składową metody etnogeograficznej jest technika kartograficzna. Metody gromadzenia informacji o określonych przejawach tradycyjnej kultury oraz ich przedstawianie w postaci mapy, nie doczekały się dostatecznego zainteresowania redaktorów i autorów map etnograficznych atlasów dotyczących ziem polskich. Niniejsze opracowanie ma pomóc w ocenie etapu powstawania map, począwszy od opracowania systematyki, ułożenia kwestionariusza oraz badań, po zamianę typów i odmian wyodrębnionych przez badacza na znaki graficzne i naniesienie ich na kartę. Niekiedy możliwe jest także pewne przetworzenie mapy, np. aby ułatwić studia porównawcze z uwzględnieniem innych map. Sądzę, iż sformułowane tu uwagi mogą także pomóc badaczom, którzy zamierzają opracowywać etnograficzne mapy w oparciu o już istniejące zbiory materiałów (np. archiwum Polskiego Atlasu Etnograficznego) lub badania nowsze.

Poniżej zajmę się zasadami tworzenia map, odwołując się do atlasów, które dotyczą ziem polskich.

\section{Atlasy etnograficzne dotyczące ziem Polski}

Atlas kultury ludowej w Polsce (dalej: AKLP), zawierający mapy obszaru II Rzeczypospolitej i będący jednocześnie pierwszym etnograficznym atlasem europejskim, opracował K. Moszyński we współpracy z J. Klimaszewską i M. Bytnarówną (1934, 1935, 1936). Autorzy zamieścili w nim 27 skartowań dotyczących różnych zagadnień z zakresu tzw. kultury duchowej³. Żródła do niego uzyskano prowadząc badania terenowe.

1 Artykuł powstał w ramach realizowanego projektu Polski Atlas Etnograficzny - opracowanie naukowe, elektroniczny katalog danych, publikacja zasobów sieci Internet, etap II. Opracowanie powstało w Archiwum Polskiego Atlasu Etnograficznego, będącym depozytem Instytutu Archeologii i Etnologii PAN w Uniwersytecie Śląskim (Wydział Sztuki i Nauk o Edukacji w Cieszynie). Archiwum kieruje dr hab. Agnieszka Pieńczak, prof. UŚ

2 Zwięzły wykład metody etnogeograficznej znajduje się w pracy K. Moszyńskiego Człowiek. Wstęp do etnografii powszechnej i etnologii (Moszyński 1958: 103-108), zob. też Pokropek (1981: 61-85); Kłodnicki (2011: 112-135); Kłodnicki, Pieńczak, Koźmińska (2017: 45-58).

3 AKLP wydrukowano ponownie z uzupełnieniami, ale bez komentarzy (Moszyński 1967: 717-743). Zob. uwaga redakcji w Moszyński (1967: 6). 
Również w pierwszej połowie lat 30. XX wieku gromadzono materiały do Atlas der deutschen Volkskunde (zob. Harmjanz, Röhr 1936-1939; Zender, Grober-Glück, Cox, Wiegelmann 1958-1979). W oparciu o zebrane wówczas dane K. Kaiser opracował Atlas der Pommerschen Volkskunde (APV) (Kaiser 1936). Obydwa atlasy obejmują ziemie należące do Niemiec przed II wojną światową. Opracowano je na podstawie badań korespondencyjnych (kwestionariusze wysłano do 20 tys. wsi), przeprowadzonych na terenie całych ówczesnych Niemiec i Austrii oraz poza ich granicami. Obydwa atlasy dotyczą różnych zagadnień, głównie z zakresu kultury duchowej i społecznej4.

Po Il wojnie światowej na ziemie zachodnie i północne napłynęli osadnicy z pozostałych ziem polskich, głównie z Kresów Wschodnich55. Cały, przyniesiony przez nich inwentarz kulturowy, uwzględniono na kartach Polskiego atlasu etnograficznego (PAE 1958-1981) obok reliktów zachowanych po autochtonach. Prace nad atlasem podjęto w końcu lat 40. XX wieku. Wywiady terenowe prowadziło ponad stu badaczy; siatka badawcza liczyła blisko 350 punktów w terenie, mniej więcej równo od siebie oddalonych. W zeszycie próbnym (1958) i pierwszych sześciu zeszytach PAE (1964-1981) dominuje tzw. kultura materialna; w nieopublikowanych trzech następnych więcej skartowań dotyczy kultury duchowej i społecznej. Wiele dziesiątków map zamieściły Agnieszka Pieńczak i Anna Drożdż w kilku tomach komentarzy do Polskiego atlasu etnograficznego.

Cenne uzupełnienie stanowi wielotomowy Atlas języka i kultury ludowej Wielkopolski zredagowany przez Z. Sobierajskiego i J. Bursztę (1979-2005). Atlas ten charakteryzuje gęsta siatka badawcza i szerokie spektrum tematyczne. W części przypadków udało się doprecyzować zasięgi zjawisk kulturowych, które na mapach PAE nie rysowały się wyraźnie na tym obszarze.

\section{Rola klasyfikacji elementów kulturowych na etapie tworzenia kwestionariusza i badań terenowych}

Przestrzeganie opisanych niżej zasad, towarzyszących tworzeniu map, umożliwia późniejsze analizy, w tym odtwarzanie genezy rozpatrywanych elementów kulturowych ${ }^{6}$

4 Sięgają do nich niektórzy polscy badacze, gdyż ułatwiają one wyjaśnienie zróżnicowania kulturowego ziem polskich w granicach po II wojnie światowej. Niektórzy pracownicy Zakładu PAE uzupełnili kilkanaście map o dane z kart ADV: kształty kopic żniwnych, formy kołysek, rodzaje pojemników do przenoszenia ziarna podczas siewu, niektóre zakazy obejmujące położnicę, dary składane zmarłym do trumny.

5 Pomijamy tu mniejsze opracowania atlasowe, jak U. Tolksdorf, Essen und Trinken in Ost- und Westpreussen (1975) oraz Atlas ludowej kultúry Slovákov v Pol'sku / Atlas kultury ludowej Słowaków w Polsce (Benža 2015)

6 Na niektóre z nich zwrócił uwagę J. Gajek we wstępach do napisanych przez siebie kwestionariuszy, według których prowadzono badania PAE (np. Gajek 1958; 1960; 1975). Odniósł się do nich również J. Bohdanowicz (1993). 
Problematyka wspomnianych atlasów jest różna i choć można znaleźć tematy wspólne, to różnice w klasyfikacji zmapowanych elementów i ich chronologii utrudniają studia porównawcze? . Poniżej zajmę się tym etapem pracy, na którym powstaje klasyfikacjå i służy jako podstawa badań, a następnie opracowywania map. W przedstawionym artykule odwołania odnosić się będą głównie do PAE9 i ułatwią ocenę opublikowanych map.

Przy wyborze tematyki badawczej i obszaru należy poznać wyniki poprzednich badań, jeśli takowe były prowadzone. W przypadku artefaktów istotną pomocą przy układaniu kwestionariusza są także zbiory muzealne i materiały archiwalne.

Jeśli badania korespondencyjne przeprowadzono w skali masowej (jak w ADV i APV), to sporządzone na ich podstawie mapy często nie zawierają informacji o braku określonych elementów kultury czy chronologii ich przemian, natomiast przynoszą zwykle dane spontaniczne o występowaniu różnych elementów, ich odmian lub wariantów ${ }^{10}$. Innej jakości są materiały zebrane przez wyszkolonych badaczy w wybranych miejscowościach. Teoretycznie, choć w praktyce nie zawsze, dają oni rękojmię właściwego doboru informatorów i pozyskania materiałów pożądanej jakości.

Dane służące do opracowania mapy winny opierać się na materiałach zgromadzonych według jednakowego kwestionariusza i - co najważniejsze - zawierającego pytania o systematycznie określone elementy kulturowe. Wcześniej zatem należy przeprowadzić podział logiczny w grupie pokrewnych sobie przedmiotów. Może to być podział dychotomiczny lub podział według pewnej zasady. Zwykle tę czynność nazywa się klasyfikacją lub systematyką. Obok tego w badaniach nad kulturą istnieje odmienny zabieg zwany typologią¹.

Klasyfikacja / typologia, oparta na danych z literatury lub/i z muzeów i zawarta w kwestionariuszu, nie zawsze bywa dokładna - dopiero analiza materiałów zebranych dla celów atlasowych umożliwia jej sprecyzowanie12. Ale teraz z kolei brak pewności, w których przebadanych wsiach występowały (lub nie) dookreślone typy lub

7 Ostatnio taką udaną próbę przeprowadziła A. Pieńczak (2016).

8 Wyrazy 'klasyfikacja' i 'systematyka' będę traktować zamiennie; podobnie określenia 'mapa' i 'karta'.

9 Także atlasy gwarowe zawierają pewną ilość map etnograficznych. O zawartości tych atlasów informują J. Reichan, K. Woźniak (2004).

10 Na niewielką skalę badania korespondencyjne o charakterze uzupełniającym prowadził także Zakład PAE.

11 Typologia to „zabieg metodologiczny (lub rezultat takiego zabiegu) polegający na grupowaniu przedmiotów na zasadzie ich podobieństwa do pewnego przedmiotu wzorcowego zwanego typem. Typologię należy odróżniać od podziału logicznego, polegającego na wyróżnieniu co najmniej dwóch klas przedmiotów, z których jedne posiadają pewną cechę, drugie zaś tej cechy nie posiadają" (Marciszewski 1988: 212).

12 Autor kwestionariusza Transport i komunikacja ląowa sformułował przeszło 20 szczegółowych pytań, odnoszących się do poszczególnych części sań roboczych, ale nie zauważył, iż na ziemiach polskich występowały one w kilku odmianach: sanie pojedyncze długie, krótkie sanie łączone w pary, krótkie sanie z włókiem (Gajek 1960: 240-260). 
odmiany badanych artefaktów lub innych elementów kulturowych. Niejednokrotnie wiąże się to z koniecznością powrotu do ponownych badań w części wsi. Do niektórych zagadnień badanych według kwestionariusza PAE nr1 (rolnictwo i hodowla) wracano w kwestionariuszu nr2. Powtarzano też część badań przeprowadzonych według kwestionariuszy nr 4 (budownictwo) i nr 5 (transport i komunikacja lądowa) Wyjątkowo decydowano się na ponowne opracowanie i druk niektórych map ${ }^{13}$. Lepszym rozwiązaniem byłoby sprawdzenie jakości kwestionariusza, prowadząc próbne badania w części wsi wyznaczonych do badań. Wyniki i ich analiza w zakresie systematyki pozwoliłyby na doprecyzowanie pytań.

Tematem mapy najczęściej są elementy kulturowe sklasyfikowane ze względu na funkcję, formę, a w odniesieniu do artefaktów także technikę wykonania i użyty materiał. Podstawowa funkcja wytworu kulturowego, często określona już w tytule mapy, w znacznym stopniu determinuje jego formę ${ }^{14}$. Widoczne jest to szczególnie w sytuacjach, gdy badano artefakty.

Autorzy map nie zawsze korzystali z istniejących systematyk, zwłaszcza jeśli dotyczyły one materiałów zgromadzonych na innych obszarach i w dodatku były znacznie wcześniejsze. Istniejące różnice w klasyfikowaniu artefaktów lub innych elementów kulturowych utrudniają studia porównawcze. Należy jednak dążyć do tego, aby opracowywana mapa zawierała jak najwięcej cech porównywalnych z innymi, tematycznie pokrewnymi mapami.

Przedmiotem klasyfikacji jest zwykle zbiór artefaktów lub innych elementów pełniących określoną funkcję w tradycyjnej kulturze, np. narzędzia do uprawy roli, obrzędy pogrzebowe. Budując systematykę badacze stają przed dylematem - czy oprzeć ją na cechach istotnych, czy nieistotnych i czym jedne różnią się od drugich. Już klasyfikacja wydawałoby się tak prostych narzędzi, jak cepy, dopuszcza różne rozwiązania (Moszyński 1967: 216-220; Kłodnicki, Kłosek, Szymański 1983). Przytoczę je poniżej, aby pokazać sposób opracowania systematyki konkretnego narzędzia.

Na terenach słowiańskich i sąsiednich posługiwano się różnymi narzędziami i sposobami młocki - młócenie przez wydeptywanie przez zwierzęta, włóczenia szerokiej płozy (tribulum), walca lub przodka wozu, młócenie przez uderzania kłosami o cokolwiek twardego lub o rodzaj drewnianego kozła. Poprzednikami cepów były kijanki. Stosowano też kije specjalnie zakończone bądź proste, ale obrobione w pewnym miejscu, tak że "miejsce to staje się podatne i może funkcjonować w ten sam mniej więcej sposób jak więź skórzana”. Dużo pospolitsze były cepy dwudzielne, w których dzierżak i bijak łączono skórzaną więzią różnego rodzaju. Zwracając uwagę na połączenie obu

13 Mapy poświęcone transportowi narzędzi rolniczych w pole (PAE, I, m. 10 oraz II, m. 66) wzbudziły wątpliwości zarówno w zakresie systematyki, jak i geografii tych narzędzi. Stąd ponowne ich badanie wg kwestionariusza nrV przeprowadzone w latach 1960-1968 i mapy 340 i 341 opublikowane w zeszycie VI PAE. 
Tab. 1.

1-3 Archaiczne/prymitywne formy zakończeń dzierżaków i bijaków w cepach; 4-10 częste formy zakończeń dzierżaków i bijaków w cepach, zob. tab.2

(1)

części K. Moszyński wyróżnił cepy jedno- i dwukapicowe, gązewkowe, ogniwkowe, dwupętlicowe i tulejkowe (Moszyński 1967: 216-220).

Im bardziej skomplikowany jest artefakt, tym trudniejsze są zabiegi klasyfikacyjne. W obrębie budownictwa wiejskiego wyróżniały się prymitywne chaty, które służyły zarówno celom mieszkalnym, jak i hodowlanym (stale lub sezonowo). Pośród nich znalazły się budynki jednoizbowe z sienią, które w pierwszej połowie XX wieku występowały już rzadko ${ }^{15}$, obok nich powszechne podczas badań terenowych PAE chałupy o układzie (komora)-izba-sień-obora/stajnia i (komora)-izba-sień-stodoła, a nawet komora-izba-sień-obora-stodoła ${ }^{16}$. Zwykle jeszcze bardziej zróżnicowany plan charakteryzował domostwa, w których nie było już miejsca dla zwierząt17. Badacze na ogół nie szukali związku między poszczególnymi cechami, takimi jak cała bryła budynku, kształt dachu, konstrukcja i użyty materiał, rozplanowanie i funkcja wnętrz, na urządzeniach ogniowych kończąc, gdyż nie było wyraźnego wymogu zaznaczonego w kwestionariuszu (Gajek 1958)18. W rezultacie powstał szereg map poświęco-

15 PAE, z. 4, m. 212, J. Pyzik.

16 PAE, z. 4, m. 219, oprac. K. Jagieła, T. Skarżyński, Z. Wiraszko; m. 222, oprac. K. Jagieła; m. 224, oprac. J. Gajek i T. Skarżyński.

17 PAE, z. IV, mapy 214-215, B. Jankowska, m. 222, oprac. K. Jagieła.

18 J. Gajek w swoim kwestionariuszu do badań budownictwa wiejskiego zobowiązywał badaczy, aby w trakcie badań w konkretnych wsiach określali typy zagród, ogrodzeń, wnętrz domostw, urządzeń 
Tab. 2.

Odmiany dwudzielnych cepów w Europie wyodrębnione na podstawie zakończenia dzierżaków i bijaków

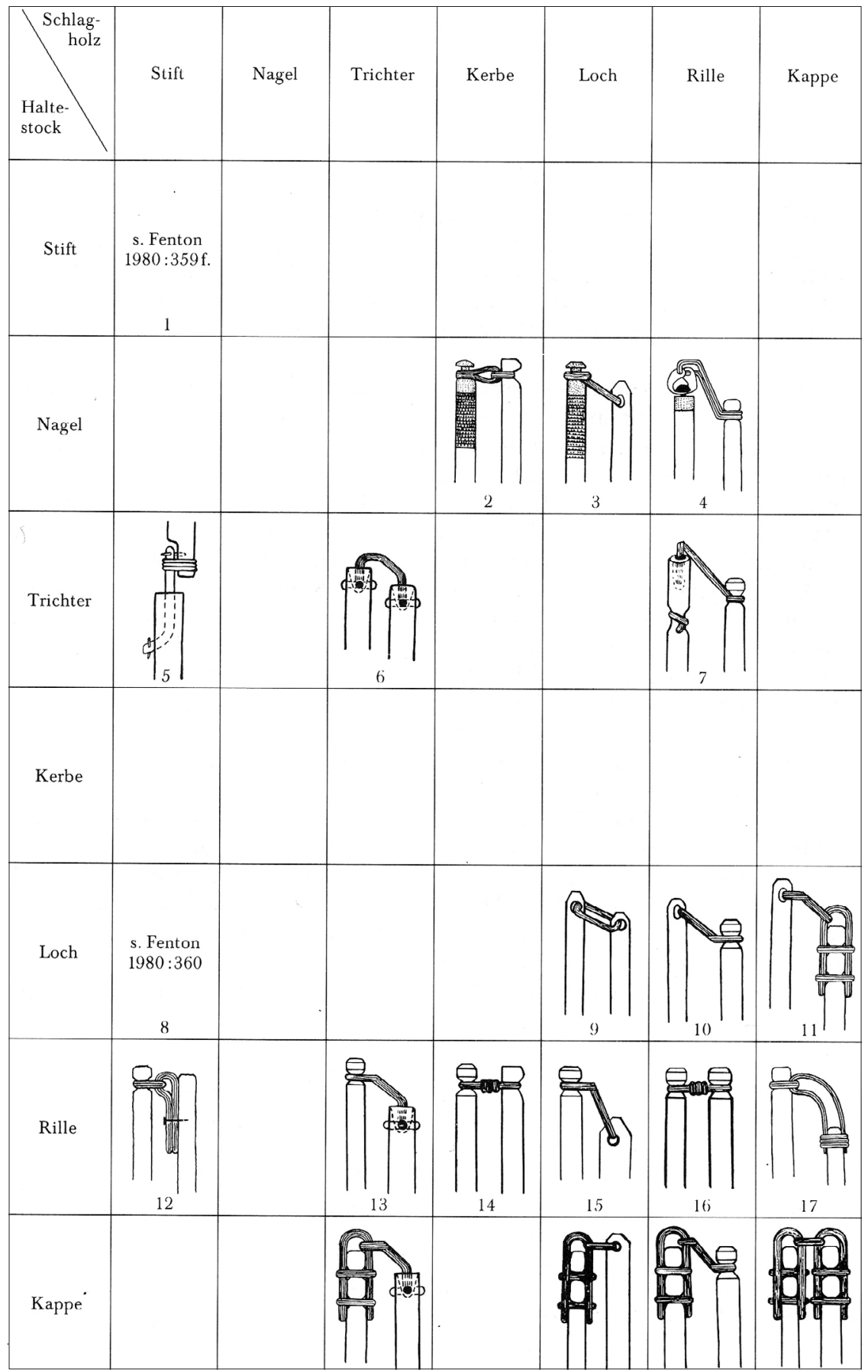


nych poszczególnym aspektom wiejskich budynków. Jeszcze raz upewniamy się, że wartość badań, ich przydatność do kreślenia map zależy od jakości kwestionariusza.

Podobne kłopoty sprawiała systematyka ubiorów ludowych. Klasyfikując elementy kulturowe w zakresie tzw. kultury społecznej i duchowej badacze również woleli wyodrębniać z całości pewne cechy, co ułatwiło przedstawianie ich na mapie, ale nie pozwalało na pełny ogląd, np. obrzędu weselnego. Sądzić należy, że włączenie metod statystycznych umożliwiłoby sporządzenia takich systematyk. Przekonaliśmy się o tym, podejmując próby całościowej klasyfikacji demonów, opierającej się na korelacji cech przypisywanych tym postaciom ${ }^{19}$

\section{Chronologiczne aspekty klasyfikowanych elementów kulturowych}

Badania winny być przeprowadzone w tym samym czasie ${ }^{20}$, z uwzględnieniem jednakich przedziałów chronologicznych. Umożliwia to uwzględnienie chronologii przedstawianych elementów co najmniej w kategoriach: „istnieją od niepamiętnych czasów i funkcjonowały podczas badań”, „istnieją od niepamiętnych czasów, ale zanikły za pamięci informatorów”, „pojawiły się w badanej miejscowości za pamięci informatorów i przetrwały do czasu badań”, „pojawiły się w badanej miejscowości za pamięci informatorów i nie przetrwały do czasu badań”, „nie istniały i nie istnieją w badanej miejscowości (nie pamiętają, aby kiedykolwiek istniały)".

Dodajmy, że badacze i autorzy map zbyt rzadko dokumentowali zmiany dokonujące się za pamięci informatorów, powszechność występowania badanego zjawiska czy jakiegoś aspektu jako pospolite, częste, rzadkie, sporadyczne/pojedyncze czy upowszechniające się lub „zanikające”. Są to zwykle informacje spontaniczne.

Mapy PAE, zarówno opublikowane (zeszyt próbny i zeszyty I-VI), jak i te przygotowane do publikacji (zeszyty VII-IX), zwykle zawierają dane o chronologii elementów kulturowych, ale przedziały czasowe często są różne, co utrudnia porównywanie geografii różnych elementów. Usiłował to uporządkować J. Gajek, redaktor PAE;

ogniowych. (Gajek 1958). „Z różnorodności form siedlisk etnografowie wyodrębnili kilka typów” pisał autor kwestionariusza, po czym, nie cytując tych ustaleń typologicznych, polecał badaczowi „wytypować we wsi kilka istotnie typowych zagród” (Gajek 1958: 20). Zalecał dokumentowanie „reprezentatywnych form rozplanowania wnętrz" (Gajek 1958: 28, 29). Zatem to badacz miał tworzyć typologię na podstawie badań nad budownictwem danej wsi. Okazało się, że z setek typologii nie da się stworzyć jednej, obowiązującej podczas kreślenia mapy. W kwestionariuszu znajdują się także pytania systematycznie określone, np. „Czy we wsi istnieją, względnie istniały chałupy szerokofrontowe z sienią na przestrzał, czy też z jednym wejściem?” (Gajek 1958: 30). Również inne pytania, np. o palenisko do gotowania i piece piekarskie (Gajek 1958: 35-41) mają charakter klasyfikacyjny.

19 Wstępne wyniki są obiecujące, choć na razie nie doprowadziły do powstania map (Kłodnicki, Diakowska-Kohut 2015).

20 Pierwsze badania nad tradycyjnym rolnictwem w Polsce przeprowadzono w ciągu jednego roku, co było możliwe dzięki zaangażowaniu kilkudziesięciu badaczy. W późniejszych badaniach brali udział pracownicy Zakładu/Pracowni PAE (4-5 osób), studenci etnografii odbywający praktyki oraz nieliczne osoby rekrutujące się spośród pracowników muzealnych i nauczycieli. Wówczas czas badań rozciągał się na 4-5 lat. 
w kwestionariuszu do badań zwyczajów i obrzędów weselnych wymagał od badaczy zebrania materiału z uwzględnieniem przedziałów czasowych:

1. z końca XIX wieku

2.sprzed I wojny światowej

3.sprzed i po II wojnie

4.z wesela współczesnego około 1965-75 r.

Przy każdym pytaniu kwestionariusza należy podawać odpowiedzi z określeniem czasu

do jakiego opis odnosi się (...). Z tak podanych 3-4 relacyj winno wynikać jasno:

a.czy we wsi badanej zwyczaj jeszcze istnieje?

b.czy istniał w przeszłości i kiedy zanikł?

c. czy nie istniał, lecz pojawił się w czasach nowszych (kiedy?)

d.czy ma charakter przeżytku? względnie reliktu? (Gajek 1975: 16).

Ostatnio zaproponowano podobny schemat uwzględniający pojawianie się, trwanie i zanikanie faktów kulturowych. Można go stosować zarówno do map już opublikowanych (w wielu przypadkach jest to możliwe), jak i w przygotowywanych do druku w czasie, gdy Zakład PAE znajdował się jeszcze we Wrocławiu (Kłodnicki, Pieńczak, 2019: 38). Tabelę znaków opracowano dla map najprostszych, gdzie zamieszczono informacje o pojedynczych i niezróżnicowanych systematycznie elementach kulturowych²1.

Tab. 3.

Zanikanie bądź pojawianie się określonego elementu kulturowego* (kształty znaków wybrano przykładowo)

\begin{tabular}{|c|c|c|c|c|c|c|}
\hline \multicolumn{7}{|c|}{ Zanikanie danego elementu kulturowego } \\
\hline 1. & 2. & 3. & 4. & 5. & 6. & 7. \\
\hline $\begin{array}{l}\text { istniał do } \\
\text { czasu badań } \\
\text { (określany } \\
\text { jako dawny) }\end{array}$ & $\begin{array}{l}\text { zanikł po } \\
\text { II wojnie } \\
\text { światowej }\end{array}$ & $\begin{array}{l}\text { zanikł } \\
\text { w okresie mię- } \\
\text { dzywojennym } \\
\text { (do II wojny } \\
\text { światowej) }\end{array}$ & $\begin{array}{l}\text { zanikł na } \\
\text { początku } \\
\text { XX wieku } \\
\text { (do I wojny } \\
\text { światowej) }\end{array}$ & $\begin{array}{l}\text { zanikł } \\
\text { w XIX wieku }\end{array}$ & $\begin{array}{l}\text { istniał, } \\
\text { ale zanikł } \\
\text { (brakuje bliższej } \\
\text { chronologii) }\end{array}$ & $\begin{array}{l}\text { brak informacji } \\
\text { o chronologii } \\
\text { (istniał lub } \\
\text { jeszcze istnieje) }\end{array}$ \\
\hline \multicolumn{7}{|c|}{ Pojawianie się danego elementu kulturowego } \\
\hline $\begin{array}{l}\text { istniał do } \\
\text { czasu badań } \\
\text { (określany } \\
\text { jako nowy) }\end{array}$ & $\begin{array}{l}\text { pojawił się } \\
\text { po II wojnie } \\
\text { światowej }\end{array}$ & $\begin{array}{l}\text { pojawił się } \\
\text { w okresie mię- } \\
\text { dzywojennym } \\
\text { (do II wojny } \\
\text { światowej) }\end{array}$ & $\begin{array}{l}\text { pojawił się } \\
\text { na początku } \\
\text { XX wieku } \\
\text { (do I wojny } \\
\text { światowej) }\end{array}$ & $\begin{array}{l}\text { pojawił się } \\
\text { w XIX wieku }\end{array}$ & $\begin{array}{l}\text { pojawił się, } \\
\text { ale już zanikł } \\
\text { (brak bliższej } \\
\text { chronologii) }\end{array}$ & $\begin{array}{l}\text { brak informacji } \\
\text { o chronologii } \\
\text { (istniał lub } \\
\text { jeszcze istnieje) }\end{array}$ \\
\hline
\end{tabular}

* Przedstawioną tabelę sporządzono w związku z projektem opracowania Atlasu dziedzictwa kulturowego wsi polskiej, mającego być wyborem map przygotowanych na nowo (Kłodnicki, Pieńczak 2019).

21 Takie mapy przedstawili Kłodnicki, Pieńczak (2019: m. 1, s. 39 i m. 2. s. 40). 
Tabela 3. zawiera siedem podstawowych określeń chronologicznych. Kilka z nich obejmuje kategorie możliwe do bliższego określenia podczas analizy danych zgromadzonych w archiwum PAE (punkty 1-5): okres prowadzenia badań terenowych (zależnie od problematyki badawczej są to najczęściej lata 50. bądź 60. XX wieku), okres powojenny (między 1945 rokiem a czasem badań), okres międzywojenny (między 1919 rokiem a II wojną światową), początek XX wieku (obejmujący czas mniej więcej do I wojny światowej) oraz najbardziej odległy czasowo XIX wiek (bliżej nieokreślone ostatnie dekady).

Dokładniejszego wyjaśnienia wymagają dwie ostatnie kategorie bez wyznaczonej dokładnej chronologii. Taka sytuacja może pojawić się w dwóch przypadkach. W pierwszym (pkt 6) stwierdzono, iż dany element kulturowy zanikł, względnie pojawił się w bliżej nieokreślonym, niemożliwym do precyzyjnego uchwycenia czasie (w materiale źródłowym znalazła się wyłącznie ogólnikowa kategoria „zanikł” albo zjawisko „nowe”). W drugim przypadku (pkt 7), w trakcie analizy materiału źródłowego, nie stwierdzono jakiejkolwiek informacji świadczącej o chronologii jego zaniku bądź pojawiania się (wiadomo jedynie o tym, że dany obiekt czy zjawisko kulturowe było znane w tradycji danej miejscowości)22.

Do rozważenia jest jeszcze propozycja, aby chronologię ukazywać szrafami. Te mogłyby być kolorowe, w różnych odcieniach. Przyjęcie określonego systemu oznaczania chronologii ułatwi porównywanie map.

\section{Opracowywanie map}

Po pokonaniu trudności klasyfikacyjnych i przeprowadzeniu badań rysowanie map nie nastręcza już większych trudności. Na podkładzie zawierającym niezbędne informacje w rodzaju sieci rzecznej, zalesienia, hipsometrii, podziałów administracyjnych, punktów orientacyjnych, np. lokalizacji większych miejscowości (w zależności od badanych zjawisk), i wreszcie siatki, nawiązującej do przebiegu południków i równoleżników (PAE, ADV), umieszcza się informacje o występowaniu sklasyfikowanych elementów kulturowych.

Klasyfikacje bywają rozbudowane, a znaki mogą przybierać różne kształty. Usystematyzowane lub wyodrębnione w drodze zabiegu typologicznego elementy przedstawia się na mapie zwykle w postaci niewielkich kółek, kwadratów, trójkątów, rzadziej innych. W ten sposób przedstawia się występowanie lub brak określonego elementu w konkretnej miejscowości. Dyferencjacji znaków dokonuje się bądź różnicując je kolorem i/bądź wypełniając je w różny sposób. Czasem wprowadza się na mapę informacje spontaniczne ${ }^{23}$; zwykle zaznacza się je podkreśleniem, „daszkiem”, szeryfem,

22 Fragment tekstu artykułu Z. Kłodnickiego i A. Pieńczak (Kłodnicki, Pieńczak 2019) przed przekładem na j. angielski.

23 Przez informacje spontaniczne rozumiem dane wiążące się z problematyką mapy, ale nie wywołane konkretnym pytaniem kwestionariusza. 
cyfrą. Mogą one dotyczyć zarówno szczegółów konstrukcyjnych, użytego materiału, jak i specyficznych funkcji lub nazw gwarowych. Nie komplikuje to systematyki, a ubogaca treść mapy. O tym, iż jest to materiał spontaniczny czytelnik orientuje się, czytając załączony do legendy tekst kwestionariusza. Dane niepewne zaznacza się pytajnikiem.

Tego rodzaju mapy nazywa się punktowymi. Przynoszą one informacje z przebadanych wsi. Milcząco zakłada się przy tym, iż przypuszczalnie reprezentują one także sąsiednie miejscowości. Nie należy jednak zaakceptować takiej koniektury na obszarach, gdzie w odmiennych konfiguracjach współwystępują różne odmiany mapowanego elementu; podobnie sytuacja kształtuje się na pograniczach. Powinno się zatem przyjąć, iż znak punktowy informuje o obecności elementu kulturowego w przebadanej miejscowości, ale jego reprezentatywność dla większego obszaru jest niepewna.

Mniej dokładne są mapy powierzchniowe. Mogą być opracowane szrafem²4 lub z użyciem linii ograniczających, nazywanych zasięgami. Z reguły opierają się one na wcześniej przygotowanych mapach punktowych i mają charakter uogólniający, ułatwiający interpretację. Szraf pozwala zaznaczyć lokalizację określonych informacji. Z kolei użycie linii ograniczających ma charakter bardziej generalizujący, gdyż zwykle obejmują one nie tylko miejscowości i okolice nacechowane obecnością analizowanego zjawiska, ale i niewielkie obszary, gdzie ich nie zanotowano lub nawet stwierdzono ich brak.

Niekiedy na jednej mapie znajdują się obydwa sposoby obrazowania - znakami punktowymi zaznaczono stwierdzoną obecność lub brak danego zjawiska kulturowego, a powierzchniowymi jakąś jego szczególną cechę, np. chronologię, nazwy gwarowe.

Mapować można artefakty, sposoby pracy, różne elementy z zakresu kultury społecznej i duchowej, nazwy gwarowe i in. Autorzy chętniej klasyfikowali elementy ze względu na ich formę (ta na ogół jest bardziej wyrazista i zróżnicowana, choć niekiedy drugorzędna) niż na ich funkcje, choć to one stanowią o zakresie map ${ }^{25}$.

Często zdarzało się, że w przebadanej miejscowości występowały dwie lub więcej odmian mapowanego elementu. W takich przypadkach w PAE do punktu w polu podstawowym, gdzie zlokalizowana jest przebadana wieś, dorysowuje się z prawej od góry znak drugiej, a nawet trzeciej odmiany. W miejscowościach leżących na ziemiach zachodnich i północnych, które przyłączono po II wojnie światowej do Polski, inwentarz kulturowy przesiedleńców wyróżniano dorysowując znaki od dołu z lewej strony. W przypadku braku informacji od ludności autochtonicznej (wyemigrowała przed badaniami), w polu podstawowym umieszczano puste kółko, które w późniejszych mapach opatrywano szeryfem wewnętrznym, na koniec (w „okresie cieszyńskim”) kreską.

W Atlasie języka i kultury ludowej Wielkopolski, Atlas der deutschen Volkskunde

24 Szrafy mogą być bardzo różne, więc nie ma obawy, że trudne do odczytania będą te określające chronologię.

25 I tak np. terminy palenia ogni obrzędowych w Europie i krajach sąsiednich były różne; na karcie z łatwością dało się je przedstawić odmiennymi znakami, ale ich różnorakie i istotne funkcje znajdują się dopiero w komentarzach (zob. Zender 1980). 
i Atlas der Pommerschen Volkskunde współwystępowanie zaznaczano rysując znaki bardzo blisko siebie; w atlasach niemieckich także dzieląc je przecinkiem, łącząc je, a nawet umieszczając jedne w drugich.

Konsekwencją badań przeprowadzonych według kwestionariusza nad występowaniem określonych systematycznie elementów kultury są również informacje o ich niewystępowaniu. Są one ważne, gdyż umożliwiają orientację co do granic występowania badanych elementów. Wcześniej na mapach PAE niewystępowanie, ale i brak informacji, zaznaczano pustym kółkiem²6. Ostatnio, w pracowni cieszyńskiej, w tomach komentarzy do PAE, w ślad za K. Moszyńskim, używa się znaku „=”, z kolei brak informacji z badanej miejscowości to „-". Pamiętać należy, iż powyższe znaki o niewystępowaniu i braku informacji odnoszą się do określonych elementów kultury, ich odmian. Jeśli zatem na mapie mamy informacje o występowaniu dwu lub więcej odmian danego zjawiska, to zróżnicowane (najlepiej kolorystycznie) będą również znaki „=" i „„”.

Wiarygodność wszystkich znaków oceniamy, zapoznając się z odpowiednimi pytaniami kwestionariusza, które zamieszczono w legendzie mapy (w PAE i ADV). Trudniej ocenić wiarygodność badacza i informatora; łatwiej już autora mapy, do czego jednak potrzebny jest dostęp do zebranych materiałów²7.

\section{Uwagi o genezie tradycyjnej kultury ludowej w Polsce w świetle metody etnogeograficznej}

Zróżnicowanie terytorialne kultury wsi polskiej od dawna przyciągało uwagę badaczy. Upowszechniało się przekonanie, iż umiejętne badania rozmieszczenia różnych elementów pozwolą na odtworzenie genezy tradycyjnej kultury. Pojawienie się atlasów umożliwiło szersze zastosowanie metody etnogeograficznej. Przedstawiono je w pracy Polski atlas etnograficzny. Historia, osiagnięcia, perspektywy badawcze (Kłodnicki, Pieńczak, Koźmińska 2017). Spróbuję je pokrótce przypomnieć i uzupełnić.

Dawniejsza kultura europejska zachowała się dłużej w północnej, nadbałtyckiej, i w południowej, alpejsko-dynarskiej części kontynentu²8. Różne elementy kultury

26 Przy czym taki znak definiowano - „Nie stwierdzono występowania”. Jest to określenie dwuznaczne, bo znaczyło albo "stwierdzono brak”, albo "nie wiadomo, czy dany element w tej miejscowości występował”. Właściwymi określeniami są - „Stwierdzono brak występowania (za pamięci informatorów)" oraz "Brak informacji o występowaniu danego elementu kulturowego”, ale znak w postaci pustego kółeczka tego nie wyjaśnia.

27 I tak np. mapy dotyczące urządzeń ogniowych opracowane przez K. Kwaśniewskiego i opublikowane w zeszycie II PAE (m. 114-115), oddano do druku przed ostatecznym ukończeniem badań terenowych, stąd ich niekompletność i pewne niedokładności, za co autor nie może odpowiadać. W podobny sposób nie można jednak wyjaśnić niedokładności na mapach K. Kwaśniewskiego dotyczących zwierząt trzymanych w izbie lub sieni (PAE, z.1, m. 56 i 57; z. 2, m. 109-110).

28 Nie wspominamy tu o Bałkanach, gdyż ich kultura przez pół tysiąca lat podlegała poważnym wpływom tureckim. Orientalizacja rozpoczęła się jeszcze wcześniej, wówczas gdy najeźdźcy 


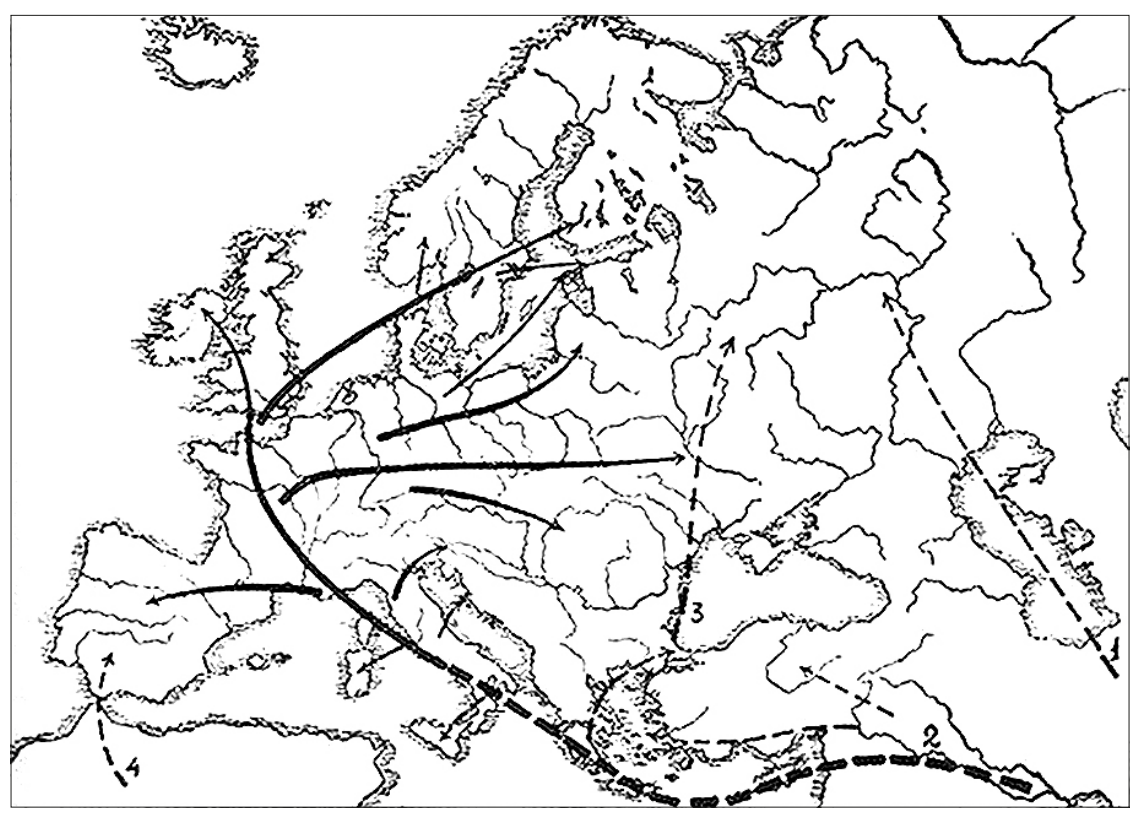

II. 1.

Kierunki zachodniego prądu kulturowego - liniami przerywanymi oznaczono kierunki dawno zamarłe

materialnej mają zasięgi „przerywane”, tj. zanotowano ich występowanie na północy i południu Europy, o czym pisał K. Moszyński (1929; 1967).

Czy bałtycką część zasięgu uznamy za równoważną z północno-wschodnią prowincją kulturową (zakładamy, iż takowa istnieje); jeśli tak, to jak wyjaśnić jej nadadriatycki odpowiednik? Obraz staje się czytelny, gdy przyjmiemy, że atlantycki prąd kulturowy, płynący od wieków od zachodu, rozbił pierwotnie względnie jednolitą kulturę tej części Europy na północno-wschodnią i dynarską (il. 1.) ${ }^{29}$.

Kierunek tego prądu kulturowego widoczny był, gdy zestawiało się zasięgi m.in. cepów kapicowych, krokwiowych dachów dwuspadowych, naramiennych nosideł nieckowatych do noszenia wody i wiele innych. Niektóre elementy szerzyły się niedawno i etnografowie mogli uchwycić ten proces in statu nascendi - oto w XIX wieku od zachodu upowszechniały się artefakty technicznie lub technologicznie doskonalsze (innowacje): żelazne brony i pługi, sanie spinane parami, młockarnie, młynki do wiania zboża, mur pruski i in.

Tradycyjna kultura Polski, tak jak przedstawiają to mapy wspomnianych atlasów, wykazuje silne związki z zachodnią Europą - jeszcze na początku XX wieku tereny

(z językiem tureckiego pochodzenia) podbili plemiona słowiańskie osiadłe na tym terenie i stworzyli państwo.

29 Zapewne także ludy pasterskie, w różnym czasie przybywające od strony Azji, osiedlając się na stepowych obszarach nadczarnomorskich i naddunajskich przyczyniały się do rozbijania kultury środkowoeuropejskiej na dwie części. 
dorzecza Odry i lewobrzeżnej Wisły stanowiły peryferie zachodnioeuropejskiej prowincji kulturowej. Fale kulturowe, rozlewając się ku wschodowi kontynentu, przemierzały obszary małoleśne, zwalniając i spiętrzając się na granicach wielkich puszcz i lasów północno-wschodniej Polski. Odbiciem tego jest tzw. północno-wschodnia rubież etnogeograficzna (Moszyński 1927; Kłodnicki 1994). W obrębie rubieży i poza nią przetrwały do początków XX wieku różne elementy cechujące wcześniejsze stadia wiejskiej kultury w Polsce; mają one swoje późne odpowiedniki na Białorusi, Litwie i dalszych obszarach północno-wschodniej Europy. Obszary te należą do północno-wschodniej

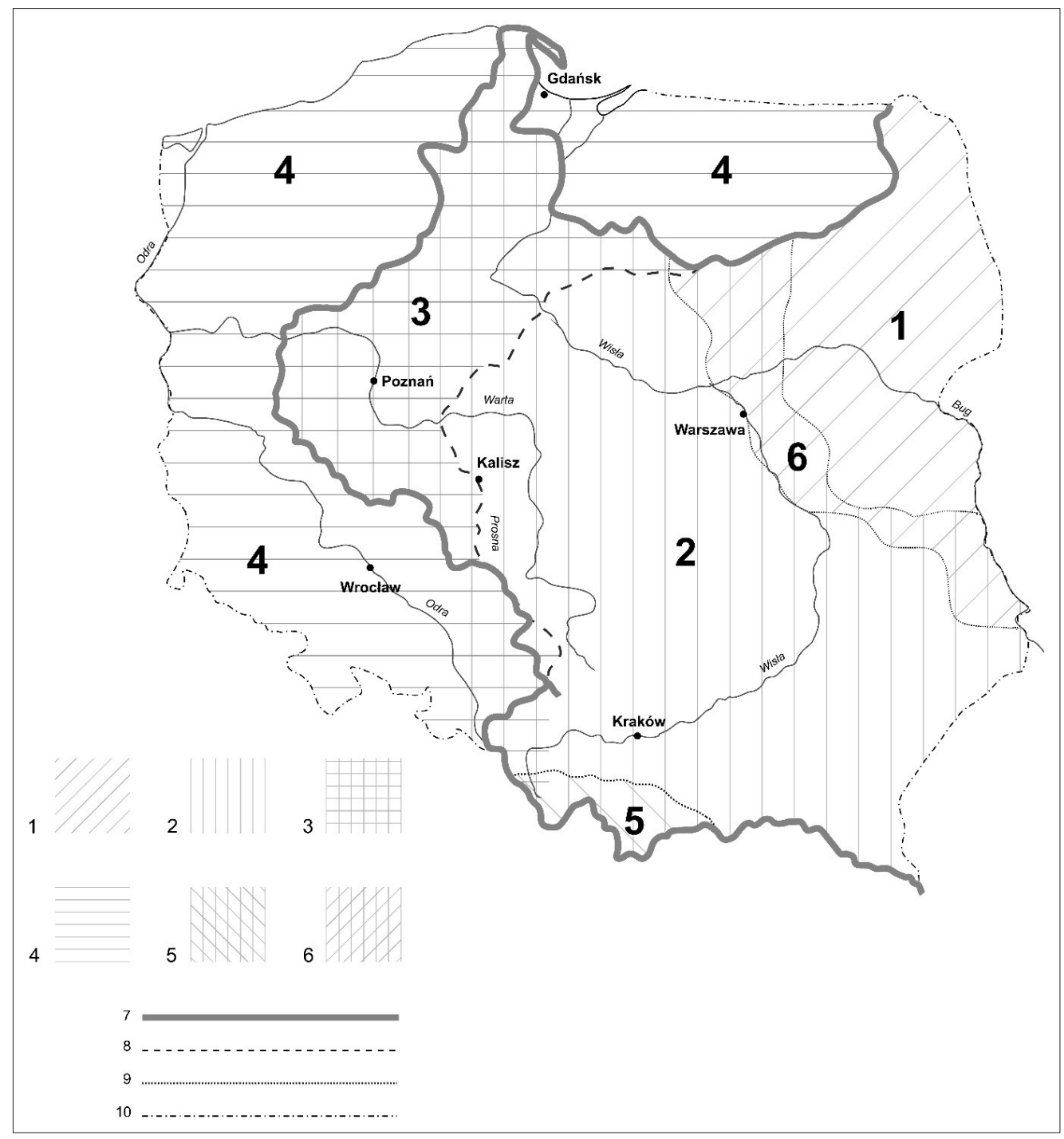

II. 2.

Zróżnicowanie tradycyjnej kultury w Polsce w I. połowie XX w. w świetle map PAE 
prowincji kulturowej i zapewne są północną częścią zasięgu przerywanego opisanego przez K. Moszyńskiego.

Prowincja północno-wschodnia: 1 - region archaiczny. Prowincja zachodnia: 2 - region środkowej i południowo-wschodniej Polski, 3 - region trzeci (górny Śląsk, Wielkopolska, Pomorze Nadwiślańskie), 4 - region 4 (dorzecze Odry, Pomorze Zachodnie, Warmia i Mazury). Inne: 5 - rubież karpacka, 6 - północno-wschodnia rubież etnograficzna. Granice: 7 - granice Polski w latach 1920-1939, 8 - granica między zaborem pruskim i rosyjskim do I wojny światowej, 9 - granice rubieży etnograficznych, 10 - granice Polski po II wojnie światowej.

Istnienia rubieży południowej domyślał się J. Czekanowski, natomiast J. Gajek traktował już ten domysł jako pewnik. Na polskim Podkarpaciu w drugiej połowie średniowiecza zderzyły się rolnicze fale osiedleńcze napływające z Powiśla, z tymi przesuwającymi się od wschodu - niosącymi ze sobą także formy pasterskie. W rezultacie w Karpatach Północnych ukształtował się obszar z zapóźnionym i częściowo odmiennym rolnictwem, zmodyfikowanym ze względu na warunki geograficzne, oraz z szałaśnictwem. To ostatnie, wprowadzone przez grupy pasterzy rumuńskich w ukraińskie Karpaty Wschodnie, szerzyło się dalej, zapewne już drogą zapożyczeń, ku zachodowi, docierając z końcem średniowiecza aż do Wołoszczyzny Morawskiej i przyległej części Śląska (Štika 2004). W ślad za J. Podolákiem, P. Slavkovskim i J. Štiką, którzy podkreślali poważną rolę hodowli owiec w gospodarce Karpat, nazwiemy tę prowincję „karpacką"30

Obydwie rubieże etnograficzne - północno-wschodnia i południowa - kształtowały się przez długie stulecia, a rola środowiska geograficznego okazała się przy tym dominująca. Natomiast w zachodniej i północnej Polsce widoczne są pogranicza, które uformowały się wskutek stosunkowo niedawnych podziałów administracyjnych. Granica rozbiorowa między Rosją a Prusami - przecinająca Polskę od okolic Katowic i Sosnowca aż po Suwalszczyznę - wyraźnie wpłynęła na częściowo odmienne ukształtowanie tradycyjnej kultury po obydwu jej stronach ${ }^{31}$.

Granica administracyjna między Niemcami a Polską, która powstała w wyniku I wojny światowej, również odzwierciedliła się w kulturze. Po stronie niemieckiej, głównie w okresie międzywojennym, dokonały się daleko idące zmiany innowacyjne, które jeszcze podczas badań PAE widoczne były zwłaszcza w rolnictwie i budownictwie. Obszar na wschód od Odry i Nysy Łużyckiej, który po II wojnie światowej

30 Na południe od łuku Karpat Północnych rozpościerają się niziny Wielkiej Kotliny Naddunajskiej Także tu dotarł ożywczy prąd kulturowy włączając dorzecze środkowego Dunaju do wspomnianej zachodnioeuropejskiej prowincji kulturowej. Z tego to powodu znajdujemy tam szereg elementów kulturowych identycznych lub podobnych do tych z terenu Polski.

31 Materiały i mapy PAE ukazują znaczące różnice kulturowe między obszarami zaboru pruskiego i tymi, które należały do Rosji. Granica przebiegała m.in. wzdłuż rzeki Prosny. Utworzyło się tu pogranicze, będące efektem ogarnięcia Wielkopolski wpływami zachodnimi; nie wszystkie dotarły poza granicę z Rosją (Brencz 1996: 188-191 i m. 42, s. 195). 
przyłączono do Polski, wyróżnia się pod względem kultury wiejskiej (Kłodnicki 2000). Na jego specyfikę wpłynęło także osadnictwo polskie.

\section{Zakończenie}

Mapy sporządzane przez etnografów mają charakter dokumentarny, ale przy zachowaniu pewnych rygorów przy ich tworzeniu często pozwalają na wnioskowanie o genezie badanych elementów kultury. Wśród stawianych im wymogów na pierwszym miejscu znajduje się klasyfikacja, uwzględniająca aspekty chronologiczne. Stanowi ona zarówno podstawę kwestionariuszy, badań, jak i map. Systematyki często są różne, co nie znaczy, że są źle opracowane ${ }^{32}$. Te różnice sprawiają, że wciąż niewiele jest studiów, w których porównuje się wybrane elementy tradycyjnej kultury polskiej z sąsiednimi33.

Powyżej przypomniano hipotezy K. Moszyńskiego o przerywanym zasięgu bałtycko-adriatyckim (Moszyński 1929) i zachodnioeuropejskim prądzie kulturowym (Moszyński 1937/1938). Ich sformułowanie było możliwe dzięki studiom etnogeograficznym. Przetestowanie tych hipotez byłoby możliwe, gdyby powstały mapy tradycyjnej kultury obejmujące cały kontynent. Wielki projekt badawczy Forschungen zum ethnologischen Atlas Europas und seiner Nachbarländer skończył się na pierwszym zeszycie poświęconym terminom palenia ogni obrzędowych (Zender 1980). Niewiele też istnieje skartowań etnograficznych obejmujących całą Europę. Warto tu przywołać mapy typów i odmian narzędzi orackich (Werth 1954; Bratanić1952), odmian cepów (Trotzig 1943), rezginii (Kłodnicki 1975). Nadzieja w mozolnym łączeniu map poświęconych elementom kulturowym w różnych krajach Europy. Map dotyczących samych tylko artefaktów jest kilka tysięcy; ich wykaz przedstawiłem niedawno (Kłodnicki, Pieńczak, Koźmińska 2017: 155-317) 34.

Hipotezy o zachodnioeuropejskim prądzie kulturowym i przerywanym zasięgu adriatycko-bałtyckim nie wyjaśniają wszystkiego. Jeszcze w pierwszej połowie XX wieku wyraźnie widoczne były różne, z reguły archaiczne, elementy, charakteryzujące rozległe obszary Europy lub nawet cały kontynent. Żywotnością zdumiewa wiele cech

32 Możemy mówić o „lokalności” systematyk, ich dopasowaniu do lokalnej specyfiki. Nadto pewien wpływ wywierają tu różnice kulturowe.

33 M. Trojan i A. Pieńczak udowodnili, iż możliwe są studia porównawcze z wykorzystaniem map ADV i PAE (Trojan 1983; Pieńczak, 2016). Inni autorzy studiów porównawczych to kolejno T. Wróblewski, M. Znamierowska-Prüfferowa, Z. Kłodnicki i R. Stolična.

34 Uzupełnienia do tego wykazu wraz z zapisami map (znowu kilka tysięcy) poświęconych kulturze społecznej i duchowej przygotowałem do druku w drugim tomie „Biblioteki Polskiego Atlasu Etnograficznego". Zainteresowanym mogę wcześniej udostępnić te zapisy drogą internetową. Liczę na to, iż niektórzy badacze zza granicy włączą się do tworzenia wykazu map, przesyłając na mój adres internetowy zapisy map według schematu: Tytuł mapy - Obszar obejmowany przez mapę - Zapis bibliograficzny. Chodzi o obszary pozapolskie; pominąć należy mapy uwzględnione w atlasach etnograficznych, gdyż te zostały już spenetrowane. 
kultury duchowej i społecznej, np. ognie obrzędowe (Zender 1980), zakazy i nakazy obowiązujące położnicę (Pieńczak 2016). Zapewne szerzyły się one dawniej, mówiąc językiem Szekspira - „na przepaściach czasu”. Czy choćby niektóre spośród nich uda się datować we współpracy z innymi dyscyplinami, głównie archeologią, historią i językoznawstwem.

Metoda etnogeograficzna przynosi tym lepsze, dokładniejsze rezultaty, gdy mapy obejmują większe obszary. Ambitnym przedsięwzięciem będzie wybór i krytyczne opracowanie etnograficznych map obszaru Polski, tak aby dały się porównać z choćby niektórymi kartami innych europejskich atlasów. Wyobrażam sobie, iż Atlas dziedzictwa kulturowego wsi polskiej, do którego rozpoczęliśmy przygotowania w Pracowni PAE, ukaże się w stulecie publikacji Atlasu kultury ludowej w Polsce, będącego pierwszym atlasem europejskim. Obydwa przedsięwzięcia - Atlas... i wcześniej wykaz map - będą milowymi krokami w zakresie etnogeografii Europy.

\section{Bibliografia}

Benža, M. (red.) (2015). Atlas ludowej kultúry Slovákov v Pol'sku / Atlas kultury ludowej Słowaków w Polsce. Kraków: Spolok Slovákov v Pol'sku / Towarzystwo Słowaków w Polsce.

Bohdanowicz, J.(1993). Polski Atlas Etnograficzny. Wykładnia zadań i metod pracy. W: Komentarze do Polskiego Atlasu Etnograficznego, t.l, cz.1 (s.7-32). Wrocław: Polskie Towarzystwo Ludoznawcze.

Bratanić, B. (1952). On the Antiquity of the One-Sided Plough in Europe, especially among the Slavic People. Laos, 2, 51-61.

Brencz, A. (1996). Wielkopolska jako region etnograficzny. Poznań: Wydawnictwo Uniwersytetu im. Adama Mickiewicza w Poznaniu.

Czekanowski, J. (1935). Zróżnicowanie etnograficzne Polski w świetle przeszłości. ,Sprawozdania z czynności i posiedzeń Polskiej Akademii Umiejętności”, 40, 64-67.

Gajek, J. (1958). Kwestionariusz do badań nad budownictwem wiejskim opracowany z udziałem pracowników Zakładu Etnografii I.H.K.M. - P.A.N. we Wrocławiu. Lud, 46, dodatek. [Kwestionariusz ten, określony w Zakładzie PAE numerem 4, używany był wcześniej w postaci maszynopisu].

Gajek, J. (1960). Transport i komunikacja lądowa. Kwestionariusz nr 5. „Archiwum Etnograficzne” nr 22. Wrocław: Polskie Towarzystwo Ludoznawcze.

Gajek, J. (1975). Kwestionariusz do badań Polskiego atlasu etnograficznego. Kwestionariusz - notatnik terenowy nrIX. Wybrane zagadnienia z zakresu kultury społecznej i duchowej. Zwyczaje i obrzędy weselne. Wrocław.

Gajek, J. (1976). Etnograficzne zróżnicowanie obszaru Polski. W: M. Biernacka (red.), Etnografia Polski. Przemiany kultury ludowej. T.1 (s. 143-172). Wrocław: Zakład Narodowy im. Ossolińskich.

Harmjanz, H., Röhr, E. (red.) (1936-1939). Atlas der deutschen Volkskunde (ADV). Z.1-6, mapy 1-120. Leipzig: Herausgegeben mit Unterstützung der Deutschen Forschungsgemeinschaft.

Kaiser, K. (1936). Atlas der Pommerschen Volkskunde. W: Pommernforschung 2. Reihe. Veröffentlichungen des Volkskundlichen Archivs für Pommern. T. 5. Greifswald: Universitätsverlag Ratsbuchhandlung I. Bamberg. 
Kłodnicki, Z. (1975). „Rezginia” in Europe. Ethnologia Europaea, 8(2), 101-110.

Kłodnicki, Z. (1994). Tak zwana rubież etnogeograficzna, a problem genezy przestrzennego zróżnicowania kultury ludowej w Polsce. Lud, 77, 47-68.

Kłodnicki, Z. (2000). Dolny Śląsk na tle ziem Polski w świetle tradycyjnej kultury materialnej. W: Z. Kłodnicki (red.), Śląsk, Schlesien, Slezsko. Przenikanie kultur (s. 93-111). Wrocław: Muzeum Narodowe we Wrocławiu.

Kłodnicki, Z. (2009). Polska - pogranicze zachodniej i północno-wschodniej prowincji kulturowej w Europie (Na podstawie Polskiego atlasu etnograficznego). Ethnologia Europae Centralis, 9, 45-59.

Kłodnicki, Z., Diakowska-Kohut, E. (2015). Demonologia ludowa - propozycje do systematyki. Z prac w archiwum Polskiego atlasu etnograficznego w Cieszynie. Ethnologia Europae Centralis, 12, 96-121.

Kłodnicki, Z., Kłosek, E., Szymański, A. (1983). Zur Systematik der Dreschflegel in Europa. Ethnologia Europaea, 13(1), 85-96.

Kłodnicki, Z., Pieńczak, A. (2019). The Atlas of Cultural Heritage of the Polish Village (a Project). Studia Etnologiczne i Antropologiczne", 19, 25-45. DOI: https//doi.org/10.31261/SEIA.2019.19.03.

Kłodnicki, Z., Pieńczak, A., Koźmińska, J.(2017). Polski atlas etnograficzny. Historia, osiągnięcia, perspektywy badawcze. Katowice: Wydawnictwo Uniwersytetu Śląskiego.

Marciszewski, W. (red.) (1988). Mała encyklopedia logiki. Wyd. 2 zmienione. Wrocław-WarszawaKraków-Gdańsk-Łódź: Zakład Narodowy im. Ossolińskich.

Moszyński, K. (1927). Lud polskiw dorzeczu Wisły. Ziemia. Miesięcznik Krajoznawczy llustrowany, 12, 163-169

Moszyński, K. (1929). Kultura ludowa Słowian. Cz. I: Kultura materialna. Kraków: Polska Akademia Umiejętności.

Moszyński, K. (1938). Niektóre przyczyny zróżnicowania kultury ludowej w Polsce. Lud Słowiański, 4(1). B65- 117. [Korzystano z nadbitki z poprawkami autora i z datą 1937 r.].

Moszyński, K. (1958). Człowiek. Wstęp do etnografii powszechnej i etnologii. Wrocław: Zakład Narodowy im. Ossolińskich - Wydawnictwo Polskiej Akademii Nauk.

Moszyński, K. (1967). Kultura ludowa Słowian. Cz. I: Kultura materialna. Wyd. drugie [nieznacznie uzupełnione]. Warszawa: Książka i Wiedza.

Moszyński, K., Klimaszewska, J., Bytnarówna, M.(1934-1936). Atlas kultury ludowej w Polsce. Z. I-III. Kraków: Polska Akademia Umiejętności.

Pieńczak. A. (2016). Obrzędowość narodzinowa na Górnym Śląsku (izolacja położnicy). „Polski atlas etnograficzny” i „Atlas der deutschen Volkskunde” w perspektywie porównawczej. Katowice: Wydawnictwo Uniwersytetu Śląskiego.

Pokropek, M. (1981). Metoda etnogeograficzna. W: Metody etnologii. Cz. 1 (s. 61-85). Warszawa: Wydawnictwo Uniwersytetu Warszawskiego.

(PAE) Polski atlas etnograficzny (red. J. Gajek). Instytut Historii Kultury Materialnej PAN: Zeszyt próbny, (1958). (mapy 1-17). Wrocław; Z.I, (1964). (mapy 1-57). Warszawa; Z. II, (1965). (mapy 58-129). Warszawa; Z. III, (1967). (mapy 130-190]). Warszawa; Z. IV, (1971). (mapy 191-250). Warszawa; Z. V. (1974). (mapy 251-304). Warszawa; Z. VI, (1981). (mapy 305-355). Warszawa.

Reichan, J., Woźniak, K. (2004). Polskie atlasy dialektologiczne i etnograficzne. Kraków: Lexis.

Sobierajski, Z., Burszta, J. (1979-2005). Atlas języka i kultury ludowej Wielkopolski. Wrocław: Zakład Narodowy im. Ossolińskich. 
Štika, J. (2004). Rozšíření a intenzita karpatské kultury na Moravě a ve Slezsku. W: J. Woitsch, F. Bahenský (red.), Etnografický atlas Čech, Moravy a Slezska, 4 (s. 77-89). Praha, Etnologický ústav Akademie věd České republiky.

Tolksdorf, U. (1975). Essen und Trinken in Ost- und Westpreussen. Cz. 1. W: Schriftenreihe der Kommission für Ostdeutsche Volkskunde in der Deutschen Gesellschaft für Volkskunde e.V.T.13. Marburg: N.G. Elwert Verlag.

Trojan, M. (1983). Dreschflegel in Europa. Methodische Probleme einer Karte. Ethnologia Europaea, 13, 203-226

Trotzig, D. (1943). Slagan och andra tröskredskap. En etnologisk undersökning med utgångspunkt från svenskt material. Stockholm: Nordiska Museets Handlingar 17.

Werth, E. (1954). Grabstock, Hacke und Pflug. Versuch einer Entstehungsgeschichte des Landbaues Ludwigsburg: Eugen Ulmer.

Zender, M. (red.) (1980). Die Termine des Jahresfeuer in Europa. Erläuterungen zur Verbreitungskarte. T.1: Forschungen zum ethnologischen Atlas Europas und seiner Nachbarländer. Göttingen: Schwartz.

Zender, M., Grober-Glück, G., Cox, H.L., Wiegelmann, L. (red.) (1958-1979). Atlas der deutschen Volkskunde, Neue Folge (ADV NF). Z.1-7. Marburg: N.G. Elvert Verlag.

\section{Spis ilustracji}

Il.1. Kierunki zachodniego prądu kulturowego (Moszyński 1937/1938)

II.2. Zróżnicowanie tradycyjnej kultury w Polsce w I. połowie XX w. w świetle map PAE. Oprac. własne.

\section{Spis tabel}

Tab.1. 1-3 Archaiczne/prymitywne formy zakończeń dzierżaków i bijaków w cepach; 4-10 częste formy zakończeń dzierżaków i bijaków w cepach (Kłodnicki, Kłosek, Szymański 1983: 92)

Tab.2. Odmiany dwudzielnych cepów w Europie wyodrębnione na podstawie zakończenia dzierżaków i bijaków (Kłodnicki, Kłosek, Szymański 1983: 90)

Tab.3. Zanikanie bądź pojawianie się określonego elementu kulturowego (kształty znaków wybrano przykładowo) (Kłodnicki, Pieńczak 2019).

\section{Streszczenie}

Jednym ze sposobów badania i prezentowania różnych przejawów tradycyjnej kultury większych obszarów jest przedstawianie ich na mapach, a następnie interpretacja przedstawionych zasięgów. Opracowanie mapy etnograficznej wymaga spełnienia pewnych rygorów już na etapie tworzenia kwestionariusza i badań terenowych. Zespół tych ściśle określonych wymogów, zawierających między innymi systematykę mapowanych elementów kultury i ich chronologię, określamy mianem techniki kartograficznej. Znajomość tej techniki umożliwia ocenę przydatności także gotowych już map do dalszych badań oraz przetwarzania ich zawartości. Może też służyć pomocą badaczom podejmującym trud opracowywania nowych map. Metoda etnogeograficzna pozwala na wnioskowanie o genezie cech/elementów kulturowych na podstawie konfiguracji ich zasięgów. Interpretacje map prowadzą etnologów do wyjaśnienia genezy tradycyjnej 
kultury w Polsce przez ukazanie, przynależności do zachodnioeuropejskiej prowincji kulturowej oraz o pograniczach z prowincjami północno-wschodnią i karpacką na ziemiach polskich. Tradycyjna kultura obszaru Polski znalazła odzwierciedlenie w kilku atlasach polskich i niemieckich.

Słowa klucze: problemy klasyfikacyjne, technika kartograficzna, metoda etnogeograficzna, rubieże i prowincje kulturowe. atlasy etnograficzne

\section{Summary}

One of the ways in which various manifestations of traditional culture on vast territories can be studied and presented is showing them on maps and, subsequently, interpreting the presented scopes. The elaboration of an ethnographic map has certain requirements already at the stage of creating the questionnaire and field studies. The set of such requirements (including the taxonomy and chronology of the mapped elements of culture) is called a cartographic technique. The familiarization with this technique enables one to estimate the usefulness of maps for further research and for processing their contents. It can also help researchers who undertake the effort of preparing new maps. The ethnogeographic method makes it possible to draw conclusions concerning the origin of cultural features/elements on the basis of the configuration of their scopes. The interpretation of maps lead ethnologists both to the explanation how traditional culture originated and to the fact of Poland's belonging to West-European cultural province and of its borderlands with North-Eastern and Carpathian provinces. In the territories of Poland, traditional culture has been reflected in several atlases - Atlas der deutschen Volkskunde, Atlas der Pommerschen Volkskunde, Atlas języka i kultury ludowej Wielkopolski, Polski atlas etnograficzny.

Keywords: classification problems, cartographic technique, ethnographical method, cultural frontiers, cultural provinces, ethnographical atlases 